Agro-Science Journal of Tropical Agriculture, Food, Environment and Extension Volume 10 Number 1 January 2011 pp. $80-90$

ISSN 1119-7455

\title{
CLIMATE CHANGE AND NIGERIAN SOILS: VULNERABILITY, IMPACT AND ADAPTATION
}

\author{
Akamigbo F. O. R. and Nnaji G. U \\ Department of Soil Science, University of Nigeria, Nsukka, Nigeria.
}

\begin{abstract}
This article reviewed the impact of climate change on our soils and suggested measures to combat or mitigate its negative effects on sustainable soil productivity. Climate change occurs when a situation in which a change in climate continues in one direction at a rapid rate and for an unusual long period of time. The article shows that Nigerian soils have high potential of susceptibility to the impact of climate change with adverse consequences. The vulnerability of our soils to impact of climate change is associated with among other things human factors, illiteracy, low level of technology applied in crop and animal production, type of soils and inadequate climate change policy and bills. Most Nigerian soils belong to the Ultisols, Alfisols, Inceptisols, Entisols, Vertisols order of the USDA Soil taxonomy and respond to climatic change differently depending on a lot of factors including their mineralogical classes. The mineralogy of Nigerian soils is dominated by low activity clays. The impacts of climatic change on soils could be positive or adverse and devastating. Some of the identified impacts are reduction in soil biodiversity, soil erosion, excessive soil wetness, high soil temperature, depletion of soil organic pool, increased soil acidity, change in soil consistence, desertification and general decrease in the overall quality of the soil for agricultural, engineering and other land uses. Based on our local condition and environment, mitigation and adaptation measures are presented in the paper for confronting climate change problems. These methods dwell on the following-management practices to be adopted by farmers, advocated government support programmes and policies and expected roles communities as well as individuals should play in reducing the negative impact of climate change on Nigerian soils. Generally, ensuring adequate cover, changing inputs and varieties and/or species of crops, making wide use of technologies in farming, creating incentive from government and reduction in deforestation and promotion of afforestation are some of the measures recommended. Research on carbon sequestration on continued basis is also recommended.
\end{abstract}

Key words: Climate change, Nigerian soils, vulnerability, adaptation.

\section{INTRODUCTION}

Soil is an important natural resource which directly or indirectly supports all forms of life on the planet earth. According to Reale et al. (1985) soil is holistically defined as a social good; it represents the physical, chemical, biological base of the agricultural production. It is the legacy from past to future generations. For some people soil is felt as the soul, the backbone or the skin of the Earth, or the placenta of life. It is a product of five soil forming factors-parent material, climate, living organism, time and relief; it is more or less dynamic. The interaction between these factors of soil formation determines the type and nature of soil formed in any given area. Climate which is the regular pattern of weather conditions of a particular place affects soil through such elements as temperature, rainfall, wind, relative humidity, solar radiation etc. The climate of an area is generally noted to be stable, that is with insignificant variation over a long period of time. For many years now, there have been reported cases of climate change across the globe. Climate change occurs when a situation in which a change in climate continues in one direction at a rapid rate and for an unusual long period of time (lasting for several years) (Anyadike, 2009). In the case of the present condition which we are experiencing, the foot print of this change is a steady and general increase in temperature (Akamigbo, 2010). Climatic change is generally believed to be caused by three major causes - astronomic, volcanic eruption and anthropogenic causes. The causes of climatic change lead to a build up of green house gases. These gases absorb the terrestrial radiations from the earth and re-radiate the heat back to 
earth, thereby leading to a general increase in temperature often referred to as global warming (Ozor, 2009a). UNISDR (2005) noted that this development is one of the threats facing the future of the world. Also, the phenomenon has been identified as one of the three problems bearing on our survival (WCED, 1987). For instance, IPCC (2007a) reported an increase in global atmospheric temperature by $0.74^{\circ} \mathrm{C}$ in the past 100 years with the associated changes in precipitation. There are evidences for longer droughts in the tropics and the sub-tropics, increasing frequency of heavy rainfall events on most land areas and for increasing intensity of tropical cyclones in North Atlantic (Prabhakar, 2009). Based on IPCC projection, the humid tropical zone of southern Nigeria which is already too hot and too wet is expected to be characterized by increase in both precipitation (especially at the peak of the rainy season) and temperature. Already, temperature increases of about $0.2^{\circ} \mathrm{C}-3^{\circ} \mathrm{C}$ per decade have been observed in the various ecological zones of the country, while drought persistence has characterized the Sudan-Sahel regions, particularly since the late 1960's. For the tropical humid zones of Nigeria, precipitation increases of about $2-3 \%$ for each degree of global warming may be expected. Thus, it is reasonable to expect that the precipitation would probably increase by approximately $5-20 \%$ in the very humid areas of the forest regions and southern savannah areas Nigeria.

In contrast, the savannah areas of northern Nigeria would probably have less rainfall, which, coupled with the temperature increases, would reduce soil moisture availability. This situation may be worsened by the expected decrease in rainfall with greater drought probabilities and larger inter-annual variability (Oladipo, 2008). Ojo (2008) noted that climate changes in Nigeria are in the form of trend in rainfall and temperature. He reported decrease in rainfall, especially since 2001 and that the relatively more recent period is characterized by generally higher temperatures than for a long term mean. In general, temperature shows an increase of about 0.2 to $0.3^{\circ} \mathrm{C}$ per decade. He stated that temperatures have generally been above normal since 1979, with relatively extreme years in 1973,1987 and 1998. In the rainforest zone, there is the probability of the dry season becoming drier, while rainy season becomes wetter due to climate change. In Guinea, Sudan and Sahel savanna zones, a decrease in rainfall and consequently drier conditions are projected.
Oladipo (2008) projected that agricultural productivity in general could decline between 10$25 \%$ by the year 2080. For some parts of the country the decline in yield in rainfed agriculture could be as much as $50 \%$. He also noted that the cost of extreme weather events could reach 5-6\% of gross domestic product by the middle of the century; a $2-3^{\circ} \mathrm{C}$ rise in temperature could reduce global output by $3 \%$ and if the rise should become 5 degrees, up to $10 \%$ of global output could be lost.

The decline in agricultural productivity may be related to influences changes in climate elements have on soil quality, especially its overall ability to support life and suitability for sustainable alternative uses. There is a strong inter-dependence between climatic factors and soil quality (Jenny, 1980). Some climatic factors that influence land degradation have been reported by WMO (2005). These include rainfall, floods, solar radiation, temperature, evaporation and wind. Climatic change will not occur without marked impacts upon various sectors of our environment, and consequently the society (Chavas et al., 2009). The vulnerability of soil to climatic influence depends on both the physical and chemical characteristics of soils. Such properties as texture, mineralogy, population and activities of soil organisms and the vegetation supported by the soil determine the extent of changes in soil characteristics that will occur in response to changing soil forming factors(i.e. climate) (Brady and Weil, 1999).

Most Nigerian soils belong to Ultisols, Alfisols, Inceptisols, Entisols, Vertisols order of the USDA Soil Taxonomy. Oxisols, Histosols and Aridisols also occur in lesser proportions. These soils belong to two major clay activity mineralogy classes; low activity and high activity classes. They are mostly dominated by the low activity clays (FDANR, 1999; Nnaji et al., 2002). They are relatively fragile soils and subject to rapid degradation under inappropriate/poor management as well as unfavourable changes in any of the soil forming factors including climate. Since the soil is one of the most important natural resources given to humanity, its quality has to be maintained or improved upon to ensure its sustainable use and prevent degradation. Changes in soil may be positive or negative and thus influence its ability to serve as a multipurpose natural resource. Certain degradation problems as flooding, desertification, erosion, salinity and acidity have been reported in many parts of the world, including Nigeria. Many researchers have attributed them to many causes, including climate change. The extreme events of climatic change can be devastating for the 
developing countries which have less capacity to adapt (Winkler, 2005; IPCC, 2007a).

The objective of this article was to review the impact of climate change on Nigerian soils and suggest measures to combat or mitigate its negative effects on sustainable soil productivity.

\section{Description of Nigeria}

Nigeria is in West Africa and is the most populous country in Africa, with a population of over 140 million ((Ojo, 2008). The country has a total land area of about 923,800 square kilometres, and occupies about $14 \%$ of West Africa but supports more that $60 \%$ of the population of the region. The country lies approximately between latitudes $4^{\circ} \mathrm{N}$ and $14^{\circ} \mathrm{N}$ and between longitudes $3^{\circ} \mathrm{E}$ and $15^{\circ} \mathrm{E}$. It is bordered on the North, East, and West by French speaking countries of Niger, Cameroon, Benin republic, respectively, while the Gulf of Guinea, an arm of the Atlantic Ocean forms the Southern boundary. The total length of the Nigerian coastline is about $835 \mathrm{~km}$ while the longest distance from North to South is about $1,200 \mathrm{~km}$ and from East to West is about $1,200 \mathrm{~km}$.

The vast area of Nigeria is typified by differences resulting from variation in climate, thus annual rainfall is less than $500 \mathrm{~mm}$ in extreme North and more than $2000 \mathrm{~mm}$ in the South. Temperature ranges $\left({ }^{\circ} \mathrm{C}\right)$ from 19 to 29 . The FMANR (1990) stated that the country is divided into five geographical regions; these are North West, North East, Middle belt, South West and South East. Politically the country is divided into six zones namely; North East, North West, North Central, South West, South East and South South.

Generally, soils in Nigeria are formed from coastal plain sands, alluvium, sand-stones and basement complex rocks. The soils are strongly weathered, have little or no content of weatherable rocks in the sand, silt fractions, and have predominantly kaolinite in the clay fractions. They have therefore low CEC, low nutrient reserve and may suffer from multiple of deficiency. Most of the soils are associated with productive problems such as inherent low fertility, predominance of kaolinite, plinthic subsoils, sometimes appearing as iron pan outcrops on eroded crests, and sandy texture. Most of the soils have low organic matter content. However, some Nigerian soils are fertile and have 2:1 clays; we have good soils along the floodplains of the major rivers etc. The mean annual rainfall and its seasonal distribution have the most influence on the nutrient disorder of soils of North West Zone (Kadeba, 1970) and other zones.

\section{Vulnerability of Nigerian soils to climate change.}

Ojo (2008) noted that the main national resources of Nigeria within the physical environment that have been identified to have high potential of suscebility to climate change with serious adverse impacts include natural ecosystems, agricultural ecosystems, water resources, coastal resources and human health. The soil is part of these ecosystems. In planning any adaptation programme to mitigate or reduce the impact of climate change on the soils of Nigeria, it is important to identify the vulnerabilities of Nigerian soils to climate change. People who perceive that they are vulnerable to impacts of climate change are more likely to respond to warnings and undertake protective measures (Micheal and Fosil, 2001). The most important forces that make our soils vulnerable to impact of climate change are human factors, which result from human interaction with the environment, i.e through human activities. Other factors include demographic factors (including population growth and migration), socio-economic factors (i.e. marked growth, urbanization and industrialization), technological factors (including poor or non-application of technology to agriculture and industries) and the peculiar topography/relief of some parts of the country. Some aspects of these factors are highlighted below.

Human activities that make our soils vulnerable to impact of climatic change include poor and inefficient irrigation practices, industrial/mining, road construction and sand excavation/evacuation with lorries (Emenike, 1988) and other activities without satisfactory measures for prevention of land degradation. Also, bush or forest fires and uncontrolled use of fire for hunting, agricultural clearing, or for settling certain social conflicts, demographic pressure (human and livestock) and deforestation resulting from land clearance for agriculture and other land uses (including unplanned urbanization, overgrazing, uncontrolled and wasteful logging, illegal felling and excessive fuel wood collection) make our soils vulnerable to climate change.

Human factors of floods include bad land use, poor management, blockage of river or drainage channels and river channels, encroachment and abuse of channels, for example, due to poor solid waste disposal techniques. Other human factors include low degree of community awareness, poor environmental education, ineffective town planning laws and poor environmental management. 
The level of illiteracy in the country also makes our soils vulnerable to climate change: more than $50 \%$ of total food production in Nigeria comes from subsistence farmers with little or no formal education. Being illiterates, they have very limited access to information on technological advances and application that could improve soil quality and make them stable to effects of changes in climatic elements. Because of the level of illiteracy there is lack of knowledge and information on some inputs i.e agro chemicals, fertilizers etc.

Low level of technology applied in production tends to accelerate the negative effects of climate change. Some machines and agrochemicals that have been fabricated and manufactured respectively, to reduce pressure on land, improve soil aggregate and aggregate stability as well as other soil conditions for higher productivity are not within the reach of farmers. This may be due to any of the following; illiteracy or lack of knowledge of these inputs, high cost of procuring such material and their non availability in the local market.

The nature of our soils reflects the parent material from which the soils form Most of our soils are sandy and contain mostly low activity clay minerals. These reduce their ability to support varied plants and microbial population that could help in stabilizing soils and reduce their vulnerability to the impact of climate change. Also, the acidic nature of most Nigerian soils, especially those in southern Nigeria influence their ability to support soil organism thereby reducing soil organic matter, macronutrients, molybdenum and boron content (Nnaji et al., 2005; FDANR, 1999).

Despite the nature of soil clays, the lack of adequate quantities of soil organic matter and other cementing agents, shallowness of some rocky soils; the niche occupied by soils in the general landform disposes the soil to certain natural disasters such as soil erosion and landslide, flooding and sedimentation with eroded or windblown materials. Consideration of the factors stated above to impact the ecosystems adversely reveals that Nigerian soils are vulnerable to impacts of climate change. Climatic change policy and bills to enhance good practices for sustainable environment are not adequate and the existing ones are not well implemented (AIAE, 2009). This may also contribute so much in making Nigerian soils vulnerable to climate change.

Impact of climatic change on soil condition
The impacts of climatic variations and climate change on Nigerian soils could be examined in their implication on floods, droughts, desertification, soil erosion etc. The top layer of the soil is one supporting most of the plant growth, and also part with higher direct interactions with climate and vegetation, and more influenced by human activities. Climate is probably the main variable that influences, directly or indirectly the topsoil, and particularly the surface layer. Other surface processes are caused by the properties of the soil itself (Pla, 2002). Climatic change has certain challenges, such as increased degradation of land and forest ecosystems, biodiversity loss, variable rainfall patterns and poor air quality (Akamigbo, 2010). Land degradation is the loss of utility or potential utility of land or decline in soil quality caused through misuse by human Barrow, 1992). This implies a decline in soil quality and productivity. Soil degradation processes are physical, biological and chemical and they include soil compaction and pulverization, salt accumulation, leaching, surface crusting and desertification, alkalization, acid rains, deforestation etc.

Reduction in soil biodiversity is of so much importance because of the improvement in soil quality due to the activities of various organisms present in the soil. Such processes of rock and mineral weathering, decomposition and mineralization of organic deposits, formation of soil colloidal material, soil detoxification, soil aeration and control of soil water and temperature regimes are directly or indirectly influenced by soil biological population and their activities. Reduction or elimination of these diverse organisms due to unfavourable environment resulting from climatic change may lead to desertification. UNEP (1986) stated that it was estimated that over the millennia, as much as two billion hectares of land that were productive biologically have been rendered unproductive through land degradation. These degradations impact negatively on the capacity of the soil/land to produce food thereby endangering the food security of the nations of the world.

The causative agents of soil erosion are water and wind. These are the natural causes but man and his activities are both causes and accelerators. Deforestation, construction, farming activities and other poor management practices of man induce soil erosion. Changes in climate on prolonged period may multiply the adverse impacts of these causative factors of soil erosion. Reduction in surface vegetative cover and heavy rain-storms, which may have resulted from climate 
change as witnessed in Nigeria and other parts of the world in recent years may lead to both increased wind and water erosion. For example, Akamigbo (2009) stated that although gully erosion which is more spectacular has existed in most southern states of Nigeria, sheet erosion which is more calamitous and pernicious to the farmer is widespread throughout the country. Advanced and growing devastating gullies dot the landscapes of Enugu, Imo, Anambra, Abia, AkwaIbom, Delta, Edo, Kogi, Benue, Plateau, Taraba states etc. Surface erosion is linked with intense precipitation events, high detachability of surface soil material and reduced infiltration. Sometimes mass erosion occurs on the steep slopes of gullies initially formed by surface erosion process. Troeh et al. (1999) noted that soil erosion causes loss of soil. They noted that about $700 \mathrm{mt} /$ ha have been the estimated soil loss for highly erodible bare, sandy soils and that an entire furrow slice (about 1000 tons/ac) could be blown away in three or four years at this rate if soil was removed uniformly from the entire surface. The quantity of soil lost through gully erosion is enormous and cannot easily be quantifiable. Emenike (1988) rightly puts it aptly thus " we tend to believe that of the four major natural disasters in Nigeria (gully erosion, flood, desertification and draught) gully erosion is the worst. This is because whereas all the disasters lead to flight from an area, hunger and death, only gully erosion leads in addition, to the disappearance of land itself'" Other soil problems associated with erosion include textural change, nutrient losses, productivity losses and sediment deposit (Brady and Weil,1999) Erosion causes loss of topsoil (most valuable component/parts of the soil). Erosion removes organic matter and fine material particles, while leaving behind mainly relatively less active coarser fractions. Also, losses in $\mathrm{N}$ and other essential nutrient elements occur under erosion. Erosion reduces soil water holding capacity, CEC, biological activity and capacity to supply nutrients for plant growth. Soil erosion results in deterioration of soil structure leaving a dense crust on the soil surface which in turn greatly reduces water infiltration and increases water runoff (Brady and Weil, 1999).

Erosion action on soil can spread soil borne pathogenic organism, thus spreading plant diseases. This is so because soil erosion entails soil particles detachment, their transportation and deposition in another spot. The detached soil particles that are most easily transported are the fine particles of organic matter, clay and other colloidal particles. Soil borne pathogenic organisms reside in these soil fractions and can be easily moved with soil particles during erosion action.

Human development and miscellaneous activities which cause climatic change have resulted in the degradation of natural resources so that where we had tropical rainforest we now have derived savannah, secondary bush oil, palm bush, compound gardens and farms, eutrophicated or polluted wetlands and so on (Akamigbo, 2009). Heavier rainfalls in Nigeria due to climate change will lead to flooding of the soil, increased water logging and excessive soil wetness in some areas. Ojo (2008) noted that flooding is influenced by precipitation, mainly in the form of rainfall that may be linked with change in the climatic condition of an area. Also Ozo (2009) noted that people living in lowlying islands and Deltas face the threat of being submerged by water due to climate change. Excessive wetness leads to low soil oxygen content and favours some biochemical reactions leading to denitrification, reduction of sulphates to hydrogen sulfide $\left(\mathrm{H}_{2} \mathrm{~S}\right)$, and production of methane (Obi, 2002; Brady and Weil, 1999).

High rainfall and temperature arising from climate change will increase rock and mineral weathering, as well as leaching of the basic cations $\left(\mathrm{Ca}^{2+}, \mathrm{Mg}^{2+}, \mathrm{Na}^{2+}\right.$, and $\left.\mathrm{K}^{+}\right)$thereby leaving the acidic cations $\left(\mathrm{Al}^{3+}\right.$ and $\left.\mathrm{H}^{+}\right)$, thus increasing soil acidity. Acid rains which are a consequence of climate change with its implications of green house gases add to the acidity of the soil. Increase in the acidity of Nigerian soils over the years has been reported by researchers (Nnaji et al., 2002). In strongly acid soils the availability of the macronutrients as well as molybdenum, and boron is curtailed. In contrast, availability of micronutrient cations is increased by low $\mathrm{pH}$, even to the extent of toxicity to plants and microorganisms (Brady and Weil, 1999; Tisdale and Nelson, 1987). Change in soil $\mathrm{pH}$ that may be associated with climate change can influence colloidal surface charge and adsorption capacity of the colloidal material.

One of the major consequences of climate change is the depletion of soil organic pool (SOP). Soil temperature is the primary determinant of microbial processes and so, increase in temperature will exacerbate the rate of mineralization leading to a decrease in the soil organic carbon pool (SOCP). With climatic change peat and other organic soils are converted to mineral soils. Lal (2004) noted that an increase in temperature would deplete the SOCP in the upper layers by $28 \%$ in the humid zone, $20 \%$ in the subhumid zone and $15 \%$ in the arid zone. 
Depletion of SOP has adverse effect on soil properties. Such adverse effects include reduction in the ability of soil to serve multipurpose functions such as environmental filter, reactor for biodegradation of contaminants, buffering of the emissions of green house gases from soil to the atmosphere, moderation of soil $\mathrm{pH}$ and temperature, improvement in aggregation and aggregate stability, absorbent of water at low moisture potentials and infiltration capacity of the soil leading to increase in plant available water capacity, source of charge density and ion exchange, ability to store and supply macro and micronutrients (Lal, 2004)

In some parts of the country climatic change is reflected in the reduction in mean annual rainfall leading to drier soil condition, that is reduction in soil available water and adversely high soil temperature. Projected increase in temperature and decrease in effective rainfall in many parts of Nigeria may decrease the productivity of soil. For instance, climate change will lead to reduction of rainfall in the SudanSahel belt, thereby making the region and their soils to be drier (AIAE, 2009) with consequent reduction in soil water content. Although there would be heavier than normal rainfall in Southern part of the country, there will be reduction in soil water retention capacity and moisture availability due to increased washing away of the finer soil particles (clay and silt) leaving the coarser particle (sand) that has low water retention capacity. Water is the main factor directly or indirectly responsible for soil and land degradation processes (Pla, 2008).
Although, the increased rainfall events due to climate change might improve rainfed agriculture in the savannah zones of Nigeria, but the drier conditions consequent upon climate change would cause more desertification and sand dune movements in the sahel regions. The consequences are imminently disastrous and also somehow advantageous. Desertification affected areas in Nigeria resulting from climate change are characterized by a reduction in the proportion of soil areas covered by vegetation. Under desertification the proportion of bare soil increases and vegetation may be reduced to isolated patches or clumps; thus leading to loss of perennial plants and causing more wind erosion. The United Nations Convention to Combat Desertification (UNCCD) acknowledges the complex interactions of human activities and climatic variations as the causes of desertification. In Nigeria, the processes of desertification are progressing southward at alarming rates (Oladipo, 2008). Table 1 shows the changes in the dominant vegetation and land use classes in Yobe state (one of the critically desertified states).

Certain soils such as the Vertisols will harden and crack so deeply as to constitute very serious impediment to infrastructural development in the sahel areas of northern Nigeria. On the other hand, soils in the floodplains of the major rivers in Nigeria and those in the delta region will suffer seasonal flooding which will be precarious to both agriculture and infrastructural development as a result of heavy and prolonged rainfall.

Table 1: Dominant vegetation and land use classes in 1976/78 and 1993/95 in Yobe State, Nigeria.

\begin{tabular}{|c|c|c|c|c|}
\hline \multirow[t]{2}{*}{ S/No. } & \multirow[t]{2}{*}{ land use category } & \multicolumn{2}{|c|}{ Area $\left(\mathrm{km}^{2}\right)$} & \multirow[t]{2}{*}{$\%$ change } \\
\hline & & $1976 / 78$ & $1993 / 95$ & \\
\hline 1. & Shrub/grasses & 14,240 & 8,674 & -39.09 \\
\hline 2. & Grasses & 3,735 & 4,578 & 22.57 \\
\hline 3. & Srub/sledge/graminiod fresh water/marsh/swamp & 1,344 & 782 & -41.82 \\
\hline 4. & Extensive (grazing) agriculture & 10,334 & 10,583 & 2.41 \\
\hline 5. & Extensive agriculture with denuded & 1,433 & 4,379 & 205.58 \\
\hline 6. & Intensive (crop) agriculture & 7,826 & 7879 & 0.68 \\
\hline 7. & Flood plain agriculture & 1,272 & 1,824 & 43.40 \\
\hline 8. & Sand dunes & 416 & 1,835 & 341.111 \\
\hline 9. & Gullies & 123 & 609 & 395.12 \\
\hline
\end{tabular}

Source: Adopted from Geomatics International Inc. (1998) 


\section{Mitigation and adaptation to climate change in relation to soil condition}

The direct and indirect effects of climate change on our soil demand that apart from making strong efforts to prevent additional adverse impacts, efforts to adapt to the impacts already occurring should be made.

The 2007 IPCC fourth assessment report presented the state of the art on the science of climate change and provided new insights on the wide range of adaptative responses available to respond to climate change. These vary from technological, through behavioural, to managerial and to policy responses, all responses that have direct and indirect employment consequences. Two sets of measures have often been advocated for in confronting climate change. These are mitigation measures (such as reduction in the emissions of greenhouse gases and black soot) to prevent degree of climatic change from becoming unmanageable; and adaptation measures (such as building irrigation systems and adjusting agricultural practices) to reduce the harm from climate change that proves unavoidable. While mitigation seeks to limit climate change by reducing the emission of GHGs and by enhancing 'sink'opportunities, adaptation aims to alleviate the adverse impacts through a widerange of system-specific actions.

Oladipo (2008) stated that a variety of options for mitigation (reduction of green house gases) exists in agriculture; they fall into three broad categories - (a)reducing emission of $\mathrm{CH}_{4}$, $\mathrm{CO}_{2}$, and nitrous oxide through efficient management of the flows of these gases in agricultural and other ecosystems (b) enhancing removal of $\mathrm{CO}_{2}$ through improved management of forestry and agro ecosystems and (c) avoiding (or displaying) emissions.

Adaptation can be both autonomous and planned (Oladipo, 2008). Autonomous adaptation is the ongoing implementation of existing knowledge and technology in response to changes in climate experienced, and planned adaptation is the increase in adaptive capacity by mobilizing institutions and policies to establish or strengthen conditions that are favourable to effective adaptation and investment in new technologies and infrastructure. Adaptation should be properly targeted to avoid negative impacts, such as increasing competition on existing resources.

In order to minimize the negative impacts of climate change, a number of mitigation and adaptation measures are open to Nigeria. Such adaptation measures would vary from one region/state to another and from one socioeconomic sector to another. These measures include: (a) Insuring that the soil is protected all the time through mulching (i.e. live, plastic and plant residue mulch). Unprotected soil surface is exposed to the direct impact of raindrops, causing disruption of soil aggregates and sealing and crusting effects. Sealing effects cause sharp decreases in water infiltration rates under wet conditions. Crusting effects refer to seals that have dried and hardened, offering resistance to seed emergence.

(b)Changing input such as crop varieties and/or species and using inputs with increased resistance to heat shock and drought; altering fertilizer rates to maintain grain or fruit quality consistent with the climate and soil condition, and altering amounts and timing of irrigation and other water management practices.

(c ) Making wider use of technologies to harvest water, to conserve soil moisture (e.g. crop residue retention) and to use water more effectively in areas where there is a decrease in rainfall.

(d) Utilizing water management to prevent water logging, erosion and nutrient leaching in areas where there is an increase in rainfall.

(e)Altering the timing and location of cropping activities.

(f)Diversifying income by integrating into farming activities additional activities such as livestock raising.

(g)Using seasonal climatic forecasting to reduce production risk and in determining best times for farm operations.

(h)Land use and land use change. This will also include the adoption of new seed, good cultivation practices that are better than the one being practiced.

(i)Creating of incentive from the government that should, for example, be in the form of targeted payment for observing soil conservation practices to cushion the effect of climate change. 
(j)Provision of insurance, safety nets and cash transfer to reduce vulnerability to climate change induced shocks

(k) Reduction of deforestation and promotion of afforestation /reforestation(planting of trees). This will increase biological carbon sequestration. Carbon sequestration implies transforming atmospheric carbon dioxide into long-lived pools and storing it securely so it is not immediately re-emitted (Lal, 2004). Currently the biosphere constitutes a carbon sink that absorbs about 2.3 gigatonnes of carbon per year, which represents about $30 \%$ of fossil-fuel emissions. Forests usually regulate stream flows, protect land from erosion, reduce flooding in adjacent areas, minimize silting of rivers, cannals and dams and contribute to a stable hydrology essential for providing stable source of water for human need and irrigated agriculture (Pla, 2008). The increasing atmospheric carbon dioxide concentration stimulates photosynthesis and consequently plant growth (IPCC, 2000). Forests stimulate more than pastures and crops in the proportion of $60 \%$ to $14 \%$. Forest trees/plants can take up carbon for 20-50 years after establishment. Research on carbon sequestration is therefore suggested as an adaptive measure for the different agroecological zones of Nigeria.

(I)Increased application of fertilizers and inoculation of beneficial organisms into the soil. When appropriate organic and inorganic fertilizers are applied to the soil, the fertility of the soil increases and plant growth is enhanced thus promoting carbon sequestration. Some organisms i.e. N-fixing organisms when inoculated into the soil improve $\mathrm{N}$ supply to crops.

Effective erosion and desertification control. This could be effected through any of these methods: closure of most foot paths inside gullies; banning illegal entry into gullies in search for stones, marbles, clay, firewood, animal feeds, fruits, etc; construction of sumps and lateral drainage gutters diagonally off all roads and major paths in towns and villages; construction of drainage systems on both sides of major roads leading to villages in gully erosion section of the town; making it mandatory on all homes/compounds to provide at least one deep well to trap rain flood emanating from the compound; construction of concrete roads and concrete drainage system in the worst sections of towns whose soils are severely prone to erosion; making arrangement for all citizens of any given town or community (whether at home or abroad) to undertake maintenance/construction/extension work on their roads, drainages, sumps at least twice each year as used to be the case in many community in the years past; grassing lawns and open spaces.

(n) Formation of an Anti-Erosion committee and subcommittees for purposes of planning and interaction with Federal Ministry of Environment and Housing and agencies connected with erosion control in each town/village /community. These committees may involve the press for the purpose of creating awareness on soil erosion and other soil degradational problems related to climate change. Communities through these committees can seek for assistance from local, state and the Federal Governments as well as NGOs for assistance. This committee will embark on sustained public enlightment on climate change and its adverse impacts.

(o) Construction of big and small water channels and gutters, damming to create artificial lakes in a number of the gullies, concrete wall embarkments and road constructions with appropriate drainage.

(p)Laws and law enforcement. Anti-erosion control committees and other soil conservation aspects in the country should be given legal backing. Rules and regulations made in relation to erosion control measures and other menaces caused by climate change should have the force of law. At present this is not the case.

(q)Local involvement on contracts execution. It is important since most contractors are interested only in contract money and not in an effective execution of contracts or the quality and health of the environment. Involvement of members of the community/town is likely to checkmate the excesses of such contractors.

(r)Nigeria should immediately enact a policy and bill to enhance good practices for sustainable environment and create climate change policy in line with the international policy. This will encourage local/national researchers to 
contribute in the fight against the adverse impact of climate change since what happens locally will eventually impact climate change globally.

(s)The following recommendations of (AIAE, 2009) should also be followed: A bill for the establishment of National Climate Change Commission (NCCC) in Nigeria with the mandate to deal with all climate change issues should be created

Commission a National Benchmark Survey (NBS) to identify the remote and immediate causes of climate change, its effects, local knowledge and practices across our six geopolitical zones.

(t)Develop National Adaptation Framework (NAF) for all the geopolitical zones in Nigeria. This will include plans for resettlement of victims of environmentally induced migration, resource conflicts, and crime and violence associated with climate risks. It will also include request from developed countries for compensations/preferential supports for vulnerable countries that produce less of the GHGs but are mostly affected by its effects.

(u)Pursue vigorously the ban on gas flaring at the National assembly. Develop technology to convert this gas for domestic use e.g. cooking gas.

(v)Going green. This implies the use of environmentally-friendly equipmet, machines, infrastructure, and technology that produce less of the GHGs. For example, improvement in rail transport, use of bio-fuels, and energy saving devices among others.

(w)Embracing emerging technologies such as biotechnology and nanotechnology. According to WBGU (2003), the use of specially designed genetically modified organisms could be a way to improve the physical and chemical condition of our soils hence making soils less susceptible to effects of climate change.

(x)State and local governments should draw up control measures and programmes aimed at integrating the negative activities that may impact and accelerate climate change in their administrative areas. They should also prioritize their expectations for Federal Government assistance in the control of major disasters that are either as a result of emergency natural havoc or those that are beyond their funding capacity. These requests should be channelled through the Federal Ministry of Environment, Housing and Urban Development,

\section{REFERENCES}

Akamigbo, F. O. R. (2009). Evironmental Degradation in Nigeria : Impacts and Rehabilitation strategies. A paper presented at a public Seminar Organized by Centrer for Environmental Management and Control, University of Nigeria, Enugu Campus. June 4, 2009.

Akamigbo, F. O. R. (2010). The role of Soil Science in combating environmental and climate change hazards. A socited paper delivered at HRH Eze Egesie Complex, Micheal Okpara University of Agriculture, Umudike, Umahia, Abia State, Nigeria on 4/02/2010.

Anyadike, R. N. C (2009). Climate Change and Sustainable development in Nigeria: Conceptual Policy Paper 10: African Institute for Applied Economics (AIAE) (eds. Eboh, E. C., N Ozor, C. Onuoha and A. Chukwu).

Barrow, C. J. (1992)Land Degradation. Cambridge University Press. New York. 295pp

Brady, N. C. and Weil, R.R. (1999). The Nature and Properties of Soil. Macmillan Publishers, New York.

Dockucheav, V. V. (1883). Russian Chernozems (Russkii Chernzems). Isreal Prog. Sc. Trans., Jerusalem, 1967.

Duckworth, J. C., Bunce, R. G. H., Malloch, A. J. C., (2000). Modelling the potential effects of Climatic change on calcareous grass lands in Atlantic European Journal of Biogeology 27:347-358.

Emenike, E. N. (1988). The Agonyof Nanka gully erosion. Mentus Printing Press, N0. 51 Owerri Road, Asata, Enugu. 33pp

Federal Ministry of Agriculture and Natural Resources (FMANR) (1990). Literature Review on Soil Fertility Investigations in Nigeria. Bobma Publishers, Ibadan. Pp9-281

Intergovernmental Panel on Climate Change (IPCC) (2007a). Climate Change 2007: the physical Science basis. Summary 
for policy makers. Contribution of Working Group1 to the Fourth Assessment Report of the Intergovernmental Panel on Climate Change. http://ipcc-wg 1.ucar.edu. cited $9^{\text {th }}$ March,

IPCC (2007). Climate change Impacts, Adaptation and VulnerabilityContribution of the Working Group 11 to the Fourth Assessment Report of the Intergovernmental panel on Climate change. Cambridge, University press.

IPCC (2007). Climate change 2007. The Scientific basis. Contribution of the Working Group 1 to the Fourth Assessment Report of the Intergovernmental panel on Climate change. Cambridge, University press.

IPCC(2007). Climate change 2007. Mitigation Contribution of the Working Group 111 to the Fourth Assessment Report of the Intergovernmental panel on Climate change. Cambridge, University press.

Jenny, H. (1980). The Soil Resource. Springer, New York.377pp

Kadeba, O. (1970). Organic matter and N status of some soils from the savanna zone of Nigeria. Proc. Inaugural Conference Forestry Association, Nigeria, Ibadan.

Lal, R. (2004). Soil carbon sequenstration impacts on global climate change and food security. Science, 304: 1623-1627

Micheal, B., Fasil, A. G. (2001). Worldwide Public Perception of flood risk in urban areas and its consequences for hydrological design in Ireland. Paper presented at the National Hydrology Seminar on Flood risk Management: Impacts and Development, Ireland.

Nnaji, G. U., Asadu, C. L. A. and J. C. Mbagwu (2002). Evaluation of the physicochemical properties of soils under selected agricultural land utilization types. Agro-Science 3:27-33.

Ojo, O. (2008) State of Nigerian Environment. A solicited Paper presented at the First National Environmental Summit, Transcorp Hilton, Abuja, 20-21 October, 2008.

Oladipo, E.O. ((2008). Climate change and sustainable livelihood greening options for Nigeria. Invited paper presented at the National Environment Summit, Transcorp Hilton Abuja, 20 $0^{\text {th }}-21^{\text {st }}$ October, 2008.

Ozor, N. (2009).' Understanding climatic change: Implications, for Nigerian Agriculture, Policy and Extension'. Paper presented at the national
Conference on 'climate Change and Nigerian Environment', organized by the Department of Geography, University of Nigeria, Nsukka, 29 June -2 July.

Ozor, N. (2009a). Implications of Clmate Change on National Development. The way forward In: Enugu Forum Policy Paper 10. (AIAE)

Pla, I. (2002). Hydrological approach to soil and water conservation. In: 'Man and Soil at the Third Millenium.'. (J. L. Rubio et al., ed.). 1:65-87. Geoforma Ed. Logrono (Spain). ISBN 84-87779-45$\mathrm{X})$

Pla, I. (2008). Dissertification under climate change and changing landuse in mediterranean environmrnts :In :Combating Dissertification: Assessment, Adaptation and Mitigation Strategies (D. Gabriels et al., eds). 3040. International Centre for Eremology. University. Ghent (Belgium). ISBN:978- 90-5989-271-2.

Prabhakar, S. V. R. K, Srinivasan, A. and Rajib, S. (2008). Mitig. Adapt. Strategy Glob. Change Doi 10.1007/s 11027-0089147-4.

Real, L. M. Nori and G. Ferrari (1995). The holistic approach through a questionnaire: from soil science towards sustainable development. In: Holistic approach to sustainable development: Interaction of soil science with different disciplines. Proceedings of Bologna Workshop $15^{\text {th }}-19^{\text {th }}$ Septemer, 1995. 44-54p.

Shahbazi, F. Jafarzadeh, A. A., Sarmaddian, F., Neyshaboury, M. R., Oustan, S., Anaya-romero,M, Lojo, M. and D. Dela Rosa (2009). Climate Change Impact on Land Capability using MicroLEIs DSS. Int. AgroPhysics 23:277-286.

Tompkins, E.L., Adger, W. N. (2003). Building resilience to climate change through adaptive management of natural resources. Working paper 27. Tyndall Center for Climate Change Research, UK, p19.

Troeh, F. R.,Hobbs,J. A. and Donahue, R. L. (1999). Soil and water conservation: Produvtivity and Environmental Protection. Printice Hall, Upper Saddle River, New Jersey. 93p

United Nations Environment Programme (UNEP) (1986). Farming systems principles for improved forest production and the control of soil degradation in the arid, semi-arid and 
Akamigbo F. O. R. and Nnaji G. U

humid tropics. ICRISAT, Hyderabard, India.

Windler, H. (2005) Climate change and developing countries. South African Journal of Science 101:355-364.
World Commission on Environment and Development (WCED) (1987). Our Common Future. Oxford University Press, Oxford.

World Metereological Organization (WMO). (2005). Climate and Land degradation. WMO-No.989, 2005. 